\title{
Learners' constructions of bullying in a South African school context
}



\begin{abstract}
Drawing on social constructionism as a theoretical paradigm, this article foregrounds learners' voices to depict the profiles of bullies and bullying victims within a cultural context of one coeducational secondary school in Hammarsdale in South Africa. The article uses qualitative data from semi-structured individual and focus group interviews as well as a participatory mapping exercise based on a narrative study of six purposefully sampled Grade 9 learners, aged between 13 and 16 years. The findings denote learners' social identities such as gender, sexual orientation, economic status, age, stature and complexion as critical determinants in the incitement and formation of bully-victim relations. The complex forms, causes and spaces of bullying are highlighted to denote its pervasiveness and the extent of the school's illpreparedness to effectively respond to bullying incidents. The study recommends education policy and practice reformists foreground learners' understanding and experiences of bullying as a basis for enhancing social inclusiveness, tolerance and safe schooling environments, for enhanced equitable quality of learning experiences for all the learners.
\end{abstract}

\section{Introduction}

Bullying is 'an aggressive behaviour' or 'harm doing', which is carried out repeatedly and over time in an interpersonal relationship characterised by an 'imbalance of power' (Olweus 1993:89). It verges more on violence than harassment because of its aggressive nature, which involves a high likelihood for serious, and sometimes permanent, physical injury (Patchin \& Hinduja 2011). Bullying further creates a hostile school environment (Patchin \& Hinduja 2016). A rapidly growing body of research over the past 15 years has shown that acts of bullying have severe long-lasting consequences for both the victim and the perpetrator (Denny et al. 2014), which has a likelihood to compromise learners' educational achievement and success (Hong \& Espelage 2016). As a widespread social problem, which compromises learners' rights to human dignity and educational welfare, inflicting devastating long-term physical, psychological and emotional effects on both the perpetrators and victims (Hymel \& Swearer 2015), bullying requires continued and renewed intervention.

Volk et al. (2016) further saw bullying as goal oriented. That is to say, the bully usually has a clearly mapped goal in mind on what benefit the act of bullying would be to him or her, for example, material possession or social status. There is no wonder, therefore, as to why bullying has been closely associated with school avoidance (Ndebele \& Msiza 2014), poor academic performance (Patchin \& Hinduja 2016), increased fear and anxiety and suicidal thoughts (Patchin \& Hinduja 2011), including long-term internalising of low self-esteem, anxiety and depression (Darney, Howcroft \& Stroud 2013), mostly suffered by its victims. 'There is no conclusion to what children who are bullied live with. They take it home with them at night. It lives inside them and eats away at them. It never ends' (Hymel \& Swearer 2015:296). According to Darney et al. (2013), not only are these learners isolated from their social circles and denied peer group interaction but they also feel incompetent, lose self-confidence and experience serious health problems.

According to Maree (2005:30), bullying and violence are very rife in South Africa and bullying in school contexts is just 'the tip of an iceberg'. In a study by Ndebele and Msiza (2014:117), respondents defined acts of bullying as 'kicking, beating, name calling, bad treatment by others, hurting other people, forcing others to do what they do not want, forcibly taking other peoples' belongings and screaming at others'. South Africa as a country experiences many violent acts in the communities, and the young population is familiar with such acts, thus they mimic them in school contexts (Maree 2005), which explains the high prevalence of bullying cases in South African schools. There is a need for more research to raise consciousness about bullying among learners and its devastating, compromising and antisocial effects on the learners' well-being and 
quality of schooling experiences. Although many studies have been conducted on bullying (Maree 2005; Patchin \& Hinduja 2016), the nexus between constructions of bullying - including perceptions on social identities, in a given context - and forms and incidents of bullying does not come out entirely clear. Bullying is a social construct, an activity undertaken and permeated through social relations; therefore, without focusing attention on the sociological nature and dynamics of bullying, we would not come to understand it better (Denny et al. 2014) and thus become unable to respond to and prevent bullying effectively.

In this article, the authors provide a glimpse of learners' constructions of bullying and their perceptions of the social identities of perpetrators and victims of bullying. In so doing, the article exposes the nature of social power relations among learners that predicate bullying and how societal dominant constructions of learners' identities play a critical role in shaping perpetrators and victims of bullying. The article also addresses the complex, often fluid, and contested forms and places of bullying, thereby exposing bullying-free zones and active bullying danger zones within a school context. The findings provide insights into the strategies and interventions that education policy and practice reformists concerned with addressing bullying in schooling context could implement, in order to enhance the quality of the learners' schooling experience.

\section{Social constructionism as a theoretical paradigm}

Social constructionism places emphasis on discourse and social relations as bases on which learners' construction of bullying and learners' identities as being victims or perpetrators of bullying are predicated (Gergen 2009). Gee (2011) saw discourse as a socially accepted association among ways of thinking, feeling, believing, valuing and acting that can be used to identify oneself as a member of a socially meaningful group. McCann and Kim (2003) posited that a discourse is not a language or a text, but a historically, socially and institutionally specific structure of statements, terms, categories and beliefs. In essence, one's reality is not just a product of natural creation but a formation of the society one identifies with (Berger \& Luckmann 1991). Therefore, discursively constituted social relations are a key phenomenon informing learners' constructions and experiences of bullying. In this regard, this article shows how the learners' constructions of bullying are complexly entangled with dominant constructions of bullying in their sociocultural context.

Social constructionism does not, however, deny external realities affecting learners' construction of bullying, although it posits that what is important in the study of humans (in this case learners) is to understand how they perceive and make sense of the world around them, for instance, in relation to bullying. This paradigm argues that it is the learners' socially and historically constituted relations that determine their meaning-making of bullying. Hence, the authors focused this article on the role of social identities and relationships in learners' constructions (meaningmaking) of bullying, as a basis to understand bullying dynamics within the school. Although social constructionists (such as Berger \& Luckmann 1991; Bruner \& WeinreichHaste 1987; Gergen 1985, 2009; Gergen \& Gergen 2000) are not in the business of dismissing reality, they do question the objective existence of meaningful reality. Their belief is that, whatever, exist does exist, but the moment we attempt to explain what there is - what is actually the case - we enter a world of discourse, which is suffused in traditions governed by culturally accepted ways of life or of being, and a myriad of socially and historically constituted sets of value preferences (Gergen 2009:161).

Rather than seeking facts and truths, this article was interested in the learners' social spaces and places (physical locations of collective interactions) - in the school - and how historically founded inventories of the learners' relationships with these spaces informed their subjective constructions and experiences of bullying. This theoretical perspective enabled the article to illuminate not only the spaces and places of bullying in the school contexts but also the broader societal constructions of violence in their community, owing to the social ills that the community presented to the learners, thereby highlighting that bullying is a social process and 'an activity that is situated within [a] cultural and historical context' (Bruner \& Weinreich-Haste 1987:1). Indeed, the learners' constructions of bullying were found to be entrenched in discursively symbolised and regulated social relationships with their school communities. When the learners narrated stories about their constructions of bullying, it was apparent that these were not only the learners' reality but also an embodied reflection of the nature of social relationships of bullying in their school, homes and communities in which they lived.

\section{Understanding bullying dynamics Profiles of perpetrators and victims of bullying}

Bullying is a sociological phenomenon that is rooted in human and social relations (Denny et al. 2014). For bullying to take place, two basic components must intersect: the perpetrator and the victim. Of course, some studies have also posited the presence of bystanders (bullying audience) as a third, but not least significant, player in bullying. Perpetrators of bullying display characteristics of being strong, nasty and angry (Ndebele \& Msiza 2014), with a strong desire to dominate, displaying little empathy (Olweus 1994), and tend to abuse peers in their social circles who are mostly non-assertive and insecure. For instance, newcomers, young, shy and intelligent learners are easy targets for bullies because of their vulnerability and social sensibility, which often render them unable to reciprocate similar violence in order to defend themselves. This is particularly the case when perpetration of bullying verges on an antisocial, selfish and socially insensitive abuse of power to inflict fear and intimidation and create social insecurity. Generally, perpetrators of bullying mostly bear dominant 
social identities - for instance, males, older learners, wealthy, tall, confident and outspoken and generally learners who are regarded in a positive light, according to the social constructions of learners' identities in a given context. On the contrary, bystanders are usually spectators in bullying incidents because they enjoy or are coerced to watch such violent acts in order to give audience and social affirmation to the bullies. Bystanders do not necessarily encourage bullying and are often unspoken victims, given the emotional and psychological distress they experience from watching some horrific acts of bullying, while they stand helpless to stop the acts of bullying (Hong \& Espelage 2012).

\section{Forms of bullying}

In South African school contexts, learners experience different forms of bullying, which are physical, emotional, psychological or cyber bullying (Hymel \& Swearer 2015). Physical bullying occurs when a learner uses overt bodily acts to gain power over peers (Schmidt, Pierce \& Stoddart 2016) and can include such acts as kicking, punching, hitting and other physical attacks (Chabalala 2011). Emotional bullying is conceived as an individual psychologically acting out of aggression from bully to the victim (Ringrose \& Renold 2010) like name-calling, mocking, use of sarcasm, threatening, belittling, social exclusion or humiliation. Psychological bullying means harming a person through emotional abuse, thus causing significant stress and interfering with a person's ability to develop healthy and stable patterns of relating to others (Chabalala 2011). This type of bullying occurs between close friends and impact one's self-esteem, and can further involve indirect actions like stealing or damaging other learners' property (Ndebele \& Msiza 2014). According to Patchin and Hinduja (2011), cyber bullying is an act adopted by learners to harass others through emails, social networks, using cell phones or computers. It is considered the cruellest of the other forms of bullying because it allows perpetrators to remain anonymous, therefore reducing individuals' sensitivity and empathy (Ang \& Goh 2010).

\section{Research design \\ Study context, methodology and data generation methods}

The research was conducted in a co-educational secondary school in Hammarsdale area, which is located on the periphery of Durban, in South Africa. This area has a history of political violence because of the most brutal black-on-black political killings in battles that took place at the peak of the apartheid violence in the 1980s. The school is located in a semi-urban area, has a population of 1350 children and has 22 classes accommodating learners from Grades 8 to 12 . This study used a qualitative narrative design to provide data on the learners' constructions of bullying. This approach enabled the study to present experiential data in a rich, complex and holistic manner and involved the examination of not only consciously told stories but also the deeper, underlying stories that learners held about bullying in the school (Creswell 2014). In this way, learners' experiences of bullying were located in context, moving away from viewing learners' stories about bullying as merely individual perceptions but more as cultural and ideological constructions that reflect not just learners' subjective constructions of bullying in the school contexts, but a bigger sociocultural context of their communities at large. Qualitative narratives added richness to the study as they enabled learners to tell stories, which were preserved in reallife memories, and therefore connected and situated in particular sociocultural contexts of these learners' schooling lives. Purposive sampling was utilised to select six learners aged between 13 and 16 from Grades 9 and 10 (Creswell 2014). These comprised a mixture of both bullies and victims of bullying. Semi-structured questions were used in both individual and focus group interviews. A participatory mapping exercise technique, which included learners drawing the profiles of bullies and bullying victims, and safe and bullying danger zones, was used. All interviews were conducted in the native language, isiZulu, to allow the participants to express their thoughts, feelings and opinions without limitations. Integrity, trust and rapport were maintained throughout the research process.

\section{Validity and trustworthiness}

Validity and trustworthiness were ensured by utilising a multiplicity of data collection methods, namely mapping (drawing) exercise and individual and focus group interviews. This allowed for data collected from different sources to be corroborated and triangulated with other sources (Creswell 2014). The choice of participants also provided rich data for the study as they were representative of a wider population of learners who had either been victims, bystanders or perpetrators of bullying. To get honest responses, the authors emphasised that the importance of the interviews was to get a true reflection of their lived experiences and not to get correct answers. The mapping exercise improved the validity of the study as the drawings provided a proof of what was actually documented by the learners as data. Trust and respect were maintained throughout the research process and with all the research participants. All interviews and discussions were conducted in isiZulu for participants to express themselves without linguistic restrictions (Creswell 2014). This allowed for a more accurate transcription and presentation of the data, and some verbatim excerpts from the recorded data were used to illustrate and support the study findings. After transcription, the participants were given the transcripts in order to confirm if the interpretations made by the researchers were the correct narrations and true reflections of their true responses. Any wrongly interpreted data were removed.

\section{Data analysis procedure}

Data were translated from the native language isiZulu into English. It was then analysed through an inductive process, which necessitated listening and re-listening to the recorded data, which aided in the identification of the patterns and themes related to the learners' construction of bullying in the school context (Creswell 2014). This was followed by 
line-by-line reading of all the transcripts for familiarity with the data and identifying sub-emerging themes related to the research question, which were then coded (DiCicco-Bloom \& Crabtree 2006). The participants helped with the selection and contextualisation of the pictures (Harley 2012). All the generated data were then discussed in relation to the study objectives, drawing insights from the literature debates in the field, the conceptual framework of the study and the original critical interpretive abilities of the researchers.

\section{Findings and discussions Learners' understanding of bullying: Victims and perpetrators}

Bullying was an intractable challenge, which learners experienced on the playground, during journey to school and in the community. The findings indicate the active roles that learners played as they perpetually negotiated the complex social and emotional spaces and places of bullying in this context. Social power and contestation over social capital and status were found to suffuse many incidents of bullying. For instance, attempts of power abuse were found to thwart learners' relationships in ways that precipitated incidents of bullying. Indeed, power abuse and contestations thereof were found to be the main catalysts triggering many bullying incidents at the school. The tendency was for learners whose social identities were perceived to embody dominant characteristics and values (gender, sexual orientation, economic status, age, stature, complexion, etc.) to inflict bullying on those whose social identities did not signify dominant notions and values of being normal. The authors found that incidents of bullying were neither triggered by genuine situations of survival nor as a means for learners to navigate their circumstances towards any noble or legitimate end. Most incidents of bullying were sheer malicious abuse of power mainly for bullies' own amusement. They were purely a wielding of power against other learners for no other reason than ceremonial and egoistic selfishness, aimed at belittling them (other learners). For instance, there was no reported scenario where bullying incidents occurred as a result of learners' contestations over basic resources or means of survival.

Learners' experiences of bullying were found to be closely linked to what they, as learners, understood and perceived as bullying. Therefore, many other incidents of bullying might not have been reported as bullying if these were not perceived as such by the participants in this study. As illustrated below, power abuse or misuse and domination were major features in learners' understanding of what constituted as bullying:

Bullying is whereby those bigger boys use to fight the smaller boys. (Participant 1 , boy aged 14 )

Bullying is when you take somebody's possessions by force. (Participant 2, boy aged 13)

Bullying is when you force someone to do something that he or she does not like. (Participant 3, girl aged 16)
Some children think that as their homes are bigger than others in the location that means they are also better than others here at school. (Participant 4, boy aged 15)

Learners who were perceived to be dominant and powerful were found to use their power to intimidate their victims who usually were the smaller boys with low social power, thus relegated as helpless against the bullies (Olweus 1994). Some learners at the school however seemed to have legitimate power vested in them; these included school prefects and the scholar patrol members who took advantage of their status as prefects in the school to bully other learners. This was mainly seen as an acceptable use of authority when understood within the context of their roles and responsibilities in the school, which Hymel and Swearer (2015) described as difficult to stop, for it affirmed the prefects' social status. In other cases, the participants explained that other learners would involve themselves in bullying that took the form of fights to protest against this abuse of power, especially when the learners thought the prefects were being vindictive or if they overplayed their roles (did more than what the learners thought were acceptable means for prefects to institute discipline, etc.) (Volk et al. 2016). Indeed, the prefects were found to exert their authority over the learners by hitting them when they did not listen or follow the instruction regarding certain codes of behaviour:

Some prefects want us to respect them as if they are our parents; they want us to bow on them, and if we don't, they hit you. (Participant 5, girl aged 13)

Some learners here fight the prefects. For example, one boy in Grade 5 fought a prefect in the toilets because he felt he was not treating him fairly, only because he was not from one of the bigger houses. (Participant 2, boy aged 13)

Another dynamic of use or abuse of power in bullying was demonstrated when older boys were found bullying the younger boys, while in some other cases, boys were using their social power of masculinities to bully girls. As illustrated below, the participants agreed that stealing was a form of bullying (Volk et al. 2016), and it usually occurred when older learners stole from younger learners, as a tactic to inflict fear, anxiety and emotional pain:

Grade 8 children are always in trouble because they have to pay for their schooling, if they don't, the bullies do it by force e.g. steal from them. (Participant 4, boy aged 15)

On a trip early this year, two boys were picking other's bags looking for money and other stuff. (Participant 3, girl aged 16)

A boy in our classroom last year was caught stealing a girl's cell phone. (Participant 2, boy aged 13)

Stealing and forceful taking of other learners' belongings was understood as a form of bullying by learners in this study. There are those who were easy targets, for example those who possessed minority social status within social groupings (Cortes \& Kochenderfer-Ladd 2014) or as constructed by the local cultures (Schmidt et al. 2016). Although the code of conduct was in place at the school to protect the learners 
from any forms of social abuse, including bullying, the learners nonetheless disobeyed and disregarded this code (Hymel \& Swearer 2015) and continuously engaged in petty criminal offences such as stealing, which, as illustrated above, the learners regarded as bullying.

As part of the participatory methods of this study, the learners were asked to engage in an exercise where they dramatically depicted the victim and perpetrator profile. Learners were asked to list what they regarded as dominant social identities of learners in the school (Figure 1). Against each dominant identity, learners were asked to write what they would regard as a subservient identity. Thus, the lefthand side indicates what the learners regarded as dominant social identity, and the right-hand side is a corresponding subservient identity. Then, learners were asked to place a red dot on the social identity which is mostly the perpetuator of bullying in the school and a blue dot on the social identity which is mostly the victim of bullying.

The victim and perpetrator profile in Figure 1 illustrates that all six participants perceived boys, learners from rich economic backgrounds, lesbians, thin learners and those with light skin complexion and short in stature as the main perpetrators of bullying. Perpetrators of bullying were generally depicted as the so-called 'normal' children. The inclusion of lesbians and short-statured learners is an interesting phenomenon. Perhaps this drew from the dominant constructions of lesbian as girls who possess masculine attributes relatively similar to boys. As for learners who were short in stature, more research is required to probe this phenomenon. There were dominant perceptions among learners in this study that short learners, especially boys, featured significantly as perpetrators of bullying. Little is known about how this might relate to the phenomena of the so-called 'short men syndrome'. The victims of bullying were generally learners who were regarded as the social minorities such as girls, those coming from low socioeconomic backgrounds, gay learners, fat learners, learners with dark facial complexions and the physically challenged, so-called 'disabled'.

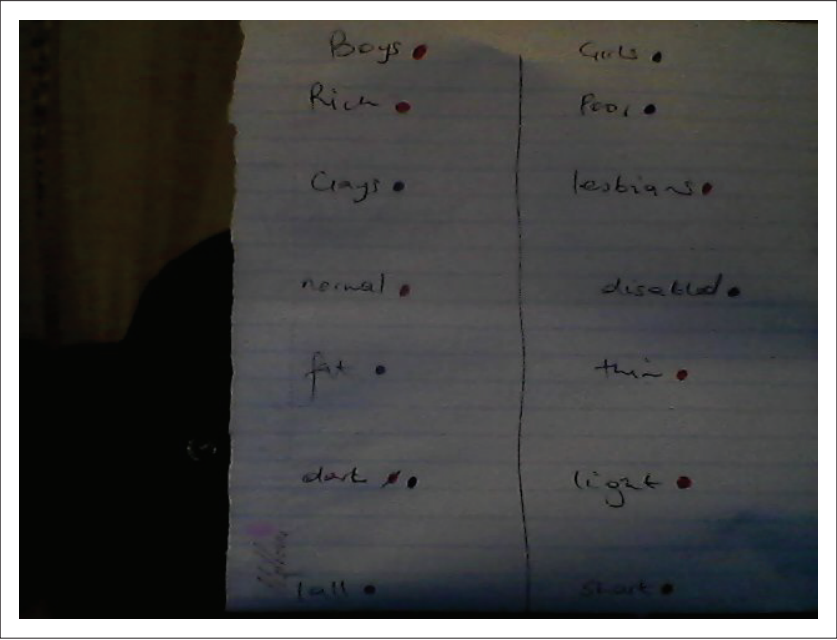

FIGURE 1: The red dots depict social identities which the participants regarded as dominant and thus perpetrators of bullying. Likewise, the blue dots show subservient social identities, which predisposed learners to be victims of bullying.
Generally, the findings indicate that the dominant social categories such as class (assumptions of poor and rich), gender, sexual orientation and learners' physical appearances play a determining role for who the perpetrators and the victims of bullying in this school were. This same pattern of the victim and perpetrator profile was prevalent in almost all learners' drawings, illustrating the currency and dominance of these phenomena in how learners constructed the victims and perpetrators of bullying in this context. Learners' understandings of bullying drew on how dynamics of power based on social identities constructions were used and acted out in conformity with the dominant culture within the school context. The low social status (Olweus 1994) accorded to learners who did not signify dominant social identities relegated them to the likelihood of becoming victims of bullying.

Another important matter that is related to the issue of power and learners' understanding of bullying is the learners' use and possession of what are regarded as dangerous weapons, such as scissors, sticks and knives, which some learners used to fight with at school:

Some children mimic TV wrestling at school especially at Grade 8 and 9 and when like one child hits another real hard and they get into a fight over that one thing. (Participant 4, boy aged 15)

One day in class, a boy claimed that he is 'Van Damme' and he called another boy 'Dolf', [popular movie actors]. He then challenged a fight because Van Damme is known as a movie star and nobody can defeat him. (Participant 3, girl aged 16)

Learners' exposure to images of bullying and violence today, via the electronic media, was found to contribute to relationships of bullying in the school (Thornberg \& Jongert 2013). Indeed, some learners' imitation of their TV screen heroes through bullying games at school subjected the targeted learners to the inhumane treatment of bullying in the form of violent wrestling games, which the bullies regarded as entertainment. Indeed, sometimes, the learners' games went too far as the perpetrators of bullying attempted to blur the distinctions between reality and TV fantasy, which often led to fights:

In Grade 10 there is a group of boys who called themselves super heroes, they used to wear those watches like Ben 10, as they saw in a TV movie and they claim that they can perform miracles as Ben 10 does. (Participant 6, girl aged 14)

From this, we can learn that challenging the taken-forgranted normality of dominant constructions of social and learners' identities, and the concomitant inequitable power relations that these forge among learners, could be a useful strategy to address bullying within the school. There was much commonness in how learners described bullying as always involving the use or misuse of power against those who are perceived as powerless (Hymel \& Swearer 2015). Therefore, the inequitable power imbalances (Olweus 1994) caused by how dominant social identities were exalted and rewarded with power and social status at the expense of minority social identities who were relegated and devalued precipitated most incidents of bullying in this context. 
Addressing general issues of poverty, economic destitution and other societal ills that relegate learners to powerlessness (Schmidt et al. 2016) could also be a long-term strategy to eradicate and mitigate bullying in this school.

\section{Complex forms, causes and spaces of bullying}

Respondents were asked to identify the various forms of bullying and the spaces and places where different forms of bullying took place. These were the spaces that the bullies used to inflict bullying because of their location within the school premises and were dubbed 'bullying danger zones'. Forms of bullying that were prevalent in this school were calling other learners by derogatory and hurtful names, physical abuse, mostly in the form of fighting, making demeaning jokes about someone (Hymel \& Swearer 2015), taking somebody's possessions by force and spreading malicious anecdotes through gossip; this latter form was inflicted especially by girls. The following are some of the examples that were offered by the learners during the interviews:

The form of bullying that is annoying in class is when the teacher asks a question then you try to answer and the other children just laugh at you. (Participant 2, boy aged 13)

Discrimination, whereby you find those who are light in colour laughing to those who are dark and call them 'kwerekwere' [a derogatory term used to refer to people who come from the middle of Africa]. (Participant 3, girl aged 16)

Touching the opposite sex without his or her permission is another form of bullying. Usually it is done by boys to girls. (Participant 1 , boy aged 14)

The findings indicate that we should pay attention to learners' well-being in the classroom, beyond reprimanding them. This could be achieved by creating a conducive classroom environment where learners can freely learn and exchange ideas without fear of being ridiculed and laughed at. Especially when learners regard being laughed at when trying to answer teachers' questions as a form of bullying, precisely because this act elicits the same feelings of being bullied, like belittlement, shame and embarrassment, effective learning is not likely to take place (Patchin \& Hinduja 2016). Bullying based on learners' complexion is a microcosm of white supremacy racial undertones, where the assumption was that the lighter in complexion one is, the closer one is to being a White person, and therefore more superior and better. Seeing the same internalised racial inferiority of blackness (Harro 2000) playing out in dynamics of bullying within a school context is a bleak indication of how pervasive and destructive this phenomenon is. It is needless to overemphasise the currency of touching other learners' private parts as a sexually charged form of bullying, mainly perpetrated by boys against girls, as participant 1 indicated above. The roots of this are implicated in unequal gender relations between boys and girls, where girls' bodies are seen or used as objects for boys' gratification and amusement (Bhana, Nzimakwe \& Nzimakwe 2011).

This was closely associated with notions of hypereroticised girls' bodies, which were supposed to be slim and heterosexually appealing. Girls who did not have this ideal body form were subjected to teasing, which learners regarded as a form of bullying. For instance, those who were regarded as thin always teased those who were fat:

I won't forget my first day here at school whereby children were laughing at me; telling me that I should run, rounding the school because I am too fat. (Participant 3, girl aged 16)

There was generally a stigma associated with not having a beautiful body, especially targeted against girls. The findings indicate that the learners' 'bodies' were a major precipitator of bullying in this context. Besides girls being bullied for not having idealised heterosexual slim bodies, some learners were bullied and teased about the size of their heads, nose, eyes, ears, chin and so forth. These would be ridiculed for being too big, too small, too pointy, too blunt, eyes too sleek and the list goes on:

Some people tease each other because they have big heads, small nose, big ears and then they start fighting. Boys also compete with their girlfriends, thinking that 'mine is prettier than yours' and if anyone says your girlfriend is ugly, the other boys laugh at you, and that too lead to fights. (Participant 6, girl aged 14)

I always hear some children teasing others because they are fat and they call them 'fatty boom boom' and those children said they will catch them on their way home and I don't know what happened after that as they were so angry. (Participant 2, boy aged 13)

Sometimes there is bullying in school because children start relationships that they can't handle and then they go to someone else and then when that person finds out it becomes a fight. (Participant 1, boy aged 14)

Some beautiful girls in the school are teased for having either a long noise or big bums. (Participant 5, girl aged 13)

The learners placed great emphasis on appearance, physical beauty and attractiveness, especially for the girls, even though it was very loosely defined. The lack of definition of what constituted a beautiful, sexually attractive appearance increased the fluidity of teasing such that at one point someone who was regarded as beautiful, and possessing the ideal body parts, could be teased and bullied as unattractive based on a particular body part that could be regarded as out of the norm. From the findings, it did not seem to matter what boys looked like, but the attractiveness of a girl seemed to matter, and as a boy, being told that a boy's girlfriend was ugly could lead to a serious fight. It appeared that a boy's girlfriend's beauty was a reflection of his real masculine and heterosexual prowess and ego. It was literally the case of the more macho the boy, the prettier the girl he was supposed to date.

Participant 3 described an incident in which a boy was seen brushing against another boy at school. The incident was reported to the teacher who happened to be passing by at the time. The teacher responded to their report by reporting the incident, ensuring that everybody in the school heard about what was regarded as a disgusting act of homosexuality - a boy trying to kiss another boy: 
Wow! they almost kissed each other those boys, the way they were brushing each other and the other boys saw them too. (Participant 3, girl aged 16)

Learners were very critical of one another and there was a social stigma attached to homosexuality. Consequently, learners had learnt to conceal any sexual orientations that did not signify heterosexuality. This ensured that the currency of homosexuality, bisexuality and other forms of learners' sexual orientations secretly prevailed under the guise of pretence and platonic relationships, where learners could not disclose even to their closest friends for fear of being bullied, victimised and rejected by their peers (Ratele 2014).

Being overly competitive was regarded as another form of bullying. Learners who demonstrated how much better off they were than others compared their homes and their school uniforms in relation to wealth, and added a layer in the dynamics of bullying in this school. Learners who were dropped at school in fancy cars, had sophisticated cell phones and lived in large houses internalised a sense of domination and superiority (Harro 2000) over other learners who did not have these material possessions. This set the scene for unproductive competitive comparison and arguments, eventually ending in acts of bullying fights:

Some of the fights in class come because of the competition of the cell phones that children use to carry at school. (Participant 5, girl aged 13)

Last year two boys were fighting because his girlfriend was dating a taxi driver as he was failing to buy her fancy cell phone and other fancy stuff, that other boy was laughing at him because of that situation, and the fight began. (Participant 4 , boy aged 15)

The availability of portable possessions, particularly the latest electronic gadgets such as cell phones, triggers and feeds jealousy and that automatically leads to fighting. (Participant 2, boy aged 13)

Competitiveness is a key dominant masculine attribute (Ratele 2014) that was found to underlie many incidents of bullying, especially because the essence of bullying was an expression of domination - a sense of personal supremacy and superiority over those who were relegated and perceived to be menial. Therefore, the bullies needed to be seen in a better light in all aspects of their lives in relation to other learners. Either the bullies had the best cell phones or they would grab things from others in the active execution of bullying. Other learners' resistance to this sparked most fighting incidents in the school. The bullies seemed to have feelings of envy, especially towards individuals perceived to have some advantages or privileges denied to them, as participant 2 illustrated above, especially connected to material possessions.

Another interesting form of bullying was territorial bullying, where older boys urinated in particular spots, and kicked and abused anyone urinating in the same spot if they were not part of the group of boys who were known to use that spot. As illustrated in Figure 2, learners were asked to actively engage in a mapping exercise in which they made drawings of places which were safe and unsafe from bullying incidents. This exercise allowed the learners to pictorially show what they regarded as the danger zones in their schooling environment.

All places that learners regarded as unsafe were denoted with a red dot and the safe ones with a blue dot. The findings indicate that the school's main gate, principal's office, staff room, passage through Grade 10 classrooms, boys' toilets, teachers' toilets and generally upper-grades classrooms were the main bullying danger zones for learners in this study. The study found that there were only a few places that were regarded as safe within the school context:

Yho madam, you know those classes [Grade 10-12] they just look at you as you are coming then make a joke of you and after that the whole class laughs at you as you pass there. (Participant 1 , boy aged 14)

Even in the toilets, madam, you will find other bullying boys who use to tell you that you must not urinate in this spot because it is mine [that is only me or my group can urinate in that spot]. (Participant 2, boy aged 13)

When you pass the arcade next to Grade 10 classes, there are older boys, who use to stand there, and they can call you and ask you to do something for them and if you refuse, they kick you or sometimes call you names. (Participant 5, girl aged 13)

Some of the places that learners regarded as bullying danger zones were far away from the teachers' staffrooms. In such spaces, the bullies could do whatever they liked without being noticed. However, some spaces such as the principal's office and teachers' toilet were indicated as bullying danger zones, which directly implicated teachers' and principal's roles in the perpetuation and infliction of bullying in the school.

The authors even found cases were teachers were reported to encourage learners to engage in acts of violence:

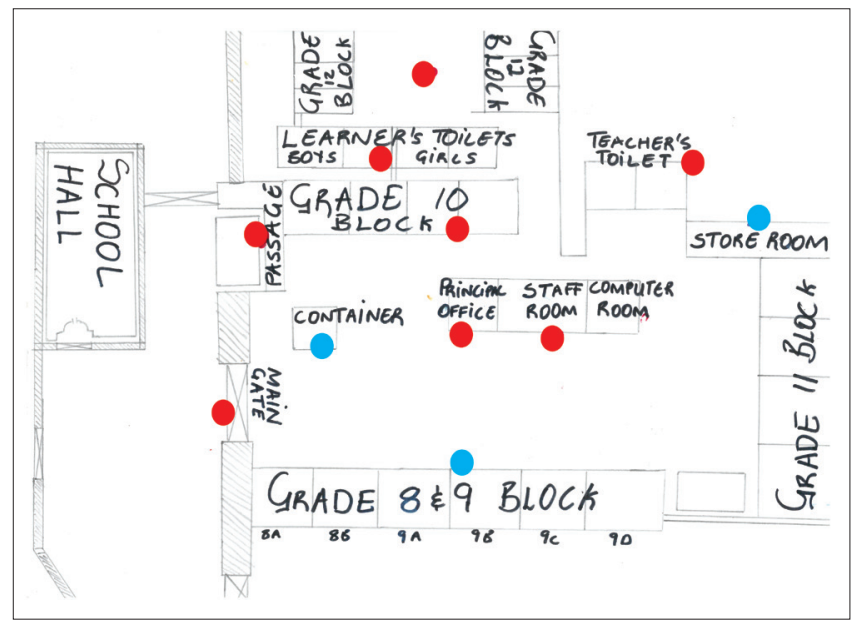

FIGURE 2: The participants collaboratively drew this figure to depict bullying danger zones and safe places in the school. The red dots denote bullying danger zones and the blue ones denote safe places. 
One day I was reporting the child who was bullying me then the teachers asked me that don't I have the hands to do what he did to me? (Participant 3, girl aged 16).

It was not uncommon for learners who reported bullying incidents to teachers to get responses like, 'Are you afraid of him?' (participant 1), simply meaning, 'Why don't you fight back?'. Perhaps such experiences might have led the participants to map the teacher's staffroom as a danger zone, with red, as also illustrated above. The teacher's response was a blatant attempt to encourage learners to respond with violence as a means to avenge bullying, thereby exacerbating rather than minimising incidents of bullying and violence in the school, which could be minimised by having positive responses to such incidents (Denny et al. 2014). The findings indicate that the container, which was used as a kitchen at the school, was one of the few places that learners regarded as safe. The motherly instinct kicked in and inspired the women who cooked in the kitchen to protect learners who were victims of bullying. Such learners would run to the container where the women cooks would hide them and pretend they did not see or know where those learners were:

Aunties in the kitchen are very wise, if you are in trouble you just run to them and they just hide you under the buckets of food. (Participant 5, girl aged 13)

The principal's office is not safe because sometimes when he is not in your favour, you report the matter to him, and then he can blame you. Only the aunties in the kitchen who can save you when you are in trouble. (Participant 6, girl aged 14)

The findings indicate that the school did not have its own policy against bullying. In fact, all members of the school who possessed dominant social status and power were the main active perpetrators of bullying - teachers, the school principal, older boys and so forth. The bullying danger zones were so widespread that they made bullying a predominant predicament in learners' schooling in this context. There were only a few safe places, considering that the participants also considered the teachers' toilet and the staffroom as places where incidents of bullying occurred. It appears that teachers' use of emotionally harmful means to reprimand learners was seen by learners as a form of bullying. Participants reported that teachers encouraged them to retaliate to bullying, and this indicated how ill-prepared teachers in the school were to deal with and to combat bullying. Therefore, it was indeed a survival of the fittest with respect to how learners navigated the schooling spaces. It was interesting to note how the container (depicted by the blue dot in Figure 2 and which was used as a kitchen), not the staffroom or the principal's office, was a place of refuge for learners who were targeted victims of bullying. Could this point to the critical role that non-teaching staff could effectively play in combatting bullying in the school? Perhaps, further research could probe more on how the non-academic staff could effectively help in this phenomenon.

\section{Limitations of the study}

The study used only six participants from one co-educational secondary school in Durban, South Africa, who provided valuable insights on bullying. Indeed, the findings are only limited to these learners' perceptions and experiences and thus cannot be generalised beyond the six participants. A longitudinal and ethnographic research project, involving more participants and various stakeholders, is planned to explore further dynamics of bullying in this context. This article focused more on the learners' constructions of bullying perpetrators and victims, and forms of bullying in a school context. Future research could benefit by eliciting more insights on the effects of bullying, especially on the victims and bystanders.

\section{Ethical considerations}

Consent for the research was sought from the Department of Education in the district and the principal of the school. Ethical clearance was then sought from the research office at the University of KwaZulu-Natal. Permission was also obtained from the parents or guardians of the participants and the participants themselves. The authors respected the notion that children are human beings who have to be given a choice to make decisions on matters concerning their lives, and the principles of voluntary participation and willingness were applied in the selection. During the study, the learners' rights and welfare were protected and pseudonyms were used to protect their identity. All parties were assured of anonymity and confidentiality.

\section{Conclusion and recommendations}

Socially constructed relationships and identities were found to play a critical role in mediating learners' constructions of bullying, as well as in shaping profiles of perpetrators and victims of bullying in the school context. Most of the learners' social identities were caught in, or at least a product of historical social relationships, which were intricately suffused in, and regulated by dominant discourses within the school. This fact made it harder for the learners to conduct their schooling lives in ways that transcend dominant predisposition as perpetrators or victims of bullying. There were cases where learners conducted themselves in ways that challenge the dominant constructions of perpetrator-victim relationships. However, such cases were defused and scattered across time and space, making it difficult to make a significant impact to alleviate adverse effects of bullying in this context. The study found that bullying incidents were mostly sheer power exercises by perpetrators, and it was difficult to comprehend the logic or pattern or procedure, beyond the supposedly minority social status of the victims, making it rather challenging to devise effective strategies to combat bullying in the learners' real-life schooling experiences.

The findings indicated that learners who were generally not affirmed by dominant social identity constructions were prone to being bullied more than those who were. For instance, victims of bullying had characteristics of being a social minority, mainly learners from low socioeconomic backgrounds, labelled as fat, and disabled. On the contrary, perpetrators had characteristics such as thin learners, light skin and short stature. 
Even teachers were found to be encouraging bullying either by not attending to cases of bullying or through encouraging learners to avenge bullying by violence. This denoted the omnipresent nature of bullying in this context, and why it is vitally important and urgent to devise strategies in order to address this social problem.

The following recommendations are made as possible ways through which bullying incidents could be prevented or mitigated in this school context:

- Teachers need to be skilled in dealing with, recognising and responding promptly and effectively to cases of bullying in the school context. This is because teachers in the study seemed to be ill-equipped to deal with cases of bullying as they were found to be perpetuating instead of mitigating violence. For instance, both pre-service education and in-service workshops could help equip teachers to respond effectively to cases of bullying and thus enhance the creation of inclusive school spaces.

- Issues of poverty (which was hugely prevalent in this context) predisposed learners to bullying incidents. Consequently, poverty alleviation strategies could be implemented in order to mitigate the effects of bullying in this school.

- Schools should design their own policies to deal with issues of bullying that adequately respond to the schools' historical and cultural positioning in order to complement a safe school environment enshrined in the values of the constitution of South Africa.

\section{Acknowledgements Competing interests}

The authors declare that they have no financial or personal relationships which may have inappropriately influenced them in writing this article.

\section{Authors' contributions}

Z.L.H. took lead in organising the field work, conducted data collection and did data transcription and some preliminary analysis. P.J.M. conceptualised the entire study and provided general guidance to N.D.M. in framing this article, as well as writing the critical aspects of the article. N.D.M. conducted and wrote the literature review sections of this study and cowrote most of the content in this article with P.J.M.

\section{References}

Ang, R.P. \& Goh, D.H., 2010, 'Cyber bullying among adolescents: The role of effective and cognitive empathy, and gender', Child Psychiatry and Human Development 41(4), 387-397. https://doi.org/10.1007/s10578-010-0176-3

Berger, P.L. \& Luckmann, T., 1991, The social construction of reality, Penguin Books, London.

Bhana, D., Nzimakwe, T. \& Nzimakwe, P., 2011, 'Gender in the early years: Boys and girls in an African working class primary school', International Journal of Educatione Development 31(5), 443-448. https://doi.org/10.1016/j.ijedudev.2010.09.001
Bruner, J.S. \& Weinreich-Haste, H., 1987, Making sense: The child's construction of the world, Methuen, London.

Chabalala, O.R., 2011, 'The nature and extent of bullying at Hwiti and Mountain View Secondary Schools Limpopo Province', master's thesis, University of Limpopo, South Africa.

Cortes, K.L. \& Kochenderfer-Ladd, B., 2014, 'To tell or not to tell: What influences children's decisions to report bullying to their teachers?' School Psychology Quarterly 29(3), 336-348. https://doi.org/10.1037/spq0000078

Creswell, J.W., 2014, Research design: Qualitative, quantitative, and mixed methods approaches, 4th edn., Sage, Los Angeles, CA.

Darney, C., Howcroft, G. \& Stroud, L., 2013, 'The impact that bullying at school has on an individual's self-esteem during young adulthood', International Journal of Education and Research 1(8), 1-16.

Denny, S., Peterson, E.R., Stuart, J., Utter, J., Bullen, P., Fleming, T. et al., 2014 'Bystander intervention, bullying and victimization: A multilevel analysis of New Zealand high schools', Journal of School Violence 14(3), 245-272. https://doi.org/ 10.1080/15388220.2014.910470

DiCicco-Bloom, B. \& Crabtree, B., 2006, 'The qualitative research interview', Medical Education 40(4), 314-321. https://doi.org/10.1111/j.1365-2929.2006 02418.x

Gee, J.P., 2011, An introduction to discourse analysis: Theory and methods, 3rd edn., Routledge, New York.

Gergen, K., 1985, 'The social constructionist movement in modern psychology', American Psychologist 40(3), 266-275. https://doi.org/10.1037/0003-066X.40.3.266

Gergen, K.J., 2009, An invitation to social constructionism, Sage, London.

Gergen, M.M. \& Gergen, K.J., 2000, 'Qualitative inquiry: Tensions and transformations', in N.K. Denzin \& Y.S. Lincoln (eds.), Handbook of qualitative research, pp. 10251046, Sage, London.

Harley, A., 2012, 'Picturing reality: Power, ethics and politics in using photo voice', International Journal of Qualitative Methods 11(4), 320-339.

Harro, B., 2000, 'The cycle of socialization', in M. Adams, W.J. Blumenfeld, R. Casteñeda, H.W. Hackman, M.L. Peters \& X. Zúniga (eds.), Readings for diversity and social justice, pp. 15-22, Routledge, New York.

Hong, J. \& Espelage, D., 2012, 'A review of research on bullying and peer victimization in school: An ecological system analysis', Aggression and Violent Behaviour 17(4), 311-322. https://doi.org/10.1016/j.avb.2012.03.003

Hymel, S. \& Swearer, S., 2015, 'Four decades of research on school bullying: An introduction', American Psychologist 70(4), 293-299. https://doi.org/10.1037/ a0038928

Maree, K., 2005, 'Bending the neck to the yoke or getting up on one's hind legs? Getting to grips with bullying', Acta Criminologia 18(2), 15-33.

McCann, C.R. \& Kim, S., 2003, Feminist theory reader, Routledge, New York.

Ndebele, C. \& Msiza, D., 2014, 'An analysis of the prevalence and effects of bullying at a remote rural school in the Eastern Cape Province of South Africa: Lessons from school principals', Studies of Tribes and Tribals 12(1), 113-124.

Olweus, D., 1993, Bullying at school: What we know and what we can do, WileyBlackwell, New York.

Olweus, D.A., 1994, 'Bullying at school: Basic facts and effects of a school based intervention program', Journal of Child Psychology and Psychiatry 35(7), 1171-1190. https://doi.org/10.1111/j.1469-7610.1994.tb01229.x

Patchin, J.W. \& Hinduja, S., 2011, 'Traditional and non-traditional bullying among youth. A test of general strain theory', Youth and Society 43(2), 727-751. https:// doi.org/10.1177/0044118X10366951

Patchin, J.W. \& Hinduja, S., 2016, 'Deterring teen bullying: Assessing the impact of perceived punishment from police, schools, and parents', Youth Violence and Juvenile Justice. https://doi.org/10.1177/1541204016681057

Ratele, K., 2014, 'Hegemonic African masculinities and men's heterosexual lives: Some uses for homophobia', African Studies Review 57(2), 115-130. https://doi. org/10.1017/asr.2014.50

Ringrose, J. \& Renold, E., 2010, 'Normative cruelties and gender deviants: The performative effects of bully discourses for girls and boys in school', British Educational Research Journal 36(4), 573-596. https://doi.org/10.1080/01411 920903018117

Schmidt, C.J., Pierce, J. \& Stoddard, S.A., 2016, 'The mediating effect of future expectations on the relationship between neighbourhood context and adolescent bullying perpetration', Journal of Community Psychology 44(2), 232-248. https:// doi.org/10.1002/jcop.21761

Thornberg, R. \& Jongert, T., 2013, 'Bystander behaviour in bullying situations: Basic moral sensitivity, moral judgment and defender self-efficacy', Journal of Adolescence 36(3), 475-483. https://doi.org/10.1016/j.adolescence. 2013.02.003

Volk, A.A., Farrell, A.H., Franklin, P., Mularczyk, P.K. \& Provenzano, D.A., 2016 , 'Adolescent bullying in schools. An evolutionary perspective', in D.C. Geary \& D.B. Berch (eds.), Evolutionary perspectives on child development and education, pp. 167-191, Springer International Publishing, Basel. 